\title{
Milestones to the Discovery of T-type Calcium Channel Blockers for the Treatment of Generalized Epilepsies
}

\author{
Olivier Bezençon ${ }^{a \star}$, Romain Siegrista ${ }^{a}$, Bibia Heidmann ${ }^{a}$, Davide Pozziª, Simon Stamma , Luboš \\ Remeň ${ }^{\mathrm{a}}$, Sylvia Richarda, Lloyd Simons ${ }^{\mathrm{b}}$, Rick Gaston ${ }^{\mathrm{b}}$, Dennis Downing ${ }^{\mathrm{b}}$, Corinna Grisostomi ${ }^{\mathrm{a}}$, \\ Catherine Roch ${ }^{a}$, Melanie Kessler ${ }^{\mathrm{a}}$, John Gatfield ${ }^{\mathrm{a}}$, Richard Moon ${ }^{\mathrm{a}}$, Thomas Pfeifer ${ }^{\mathrm{a}}$, Johannes \\ Mosbachera, Isabelle Reymond ${ }^{a}$, Eric A. Ertel ${ }^{\mathrm{a}}$, Ruben de Kanter ${ }^{\mathrm{a}}$, Bruno Capeleto ${ }^{\mathrm{a}}$, Elvire Fourniera, \\ Markus Rey ${ }^{a}$, Luca Moccia ${ }^{a}$, Michael Toeroek-Schafroth ${ }^{a}$, René Roscher ${ }^{\mathrm{a}}$, and Benno Schindelholz ${ }^{\mathrm{a}}$
}

\begin{abstract}
We describe the discovery and optimization of new, brain-penetrant T-type calcium channel blockers. We present optimized compounds with excellent efficacy in a rodent model of generalized absence-like epilepsy. Along the fine optimization of a chemical series with a pharmacological target located in the CNS (target potency, brain penetration, and solubility), we successfully identified an Ames negative aminopyrazole as putative metabolite of this compound series. Our efforts culminated in the selection of compound $\mathbf{2 0}$, which was elected as a preclinical candidate.
\end{abstract}

Keywords: Absence epilepsy · Ames test · Lead optimization · T-type calcium channel blockers

\section{Introduction}

Nature has developed numerous processes that allow transmission of information between cells and organs at different locations in our body. A signal coming from the extracellular space has to be translated into an event inside the cell. G-protein coupled receptors (GPCR) or cytokine receptors, for instance, usually transmit signals by binding a ligand coming from outside of the cell. This type of signal transduction is rather slow ( $>1 \mathrm{~s})$, and usually occurs locally, as the ligand has to diffuse in the extracellular fluid to the exact location of the receptor. If such a ligand has to be transported over a long distance, the body uses blood, or lymph, or a form of active transport. For fast and highly directed transmission, be it for short or longer distances, nature relies on a different system and uses electrical signals.

${ }^{*}$ Correspondence: Dr. O. Bezençon

E-mail: olivier.bezencon@idorsia.com

aldorsia Pharmaceuticals Ltd

Hegenheimermattweg 91, CH-4123 Allschwil

${ }^{b}$ Kalexsyn, Inc.

4502 Campus Drive, Kalamazoo, MI 49008, USA
For instance, the rapid signal transmission along the nerve fibres occurs by electrical impulses and the rapid contraction of muscle cells finds its origin in an electrical signal as well. In organs, transmission of an electrical signal generally means conveying a change in transmembrane voltage along a cell membrane or transferring a change from one membrane to another. Such signals proceed at speeds varying from around $1 \mathrm{~m} / \mathrm{s}$ up to $100 \mathrm{~m} / \mathrm{s}$ along the neuronal axon. ${ }^{[1]}$ Transmembrane voltages exist because nature has developed means to build differential ion concentrations across cell membranes, thereby creating electrochemical gradients, which result in potential differences. In turn, rapid changes in transmembrane voltage occur through the controlled breaching of one or more of these electrochemical gradients and the rapid, passive diffusion of cations $\left(\mathrm{H}^{+}, \mathrm{Na}^{+}\right.$, $\mathrm{K}^{+}$or $\left.\mathrm{Ca}^{2+}\right)$, or anions $\left(\mathrm{Cl}^{-}\right)$, through specific pores (channels) through the cell membranes. As an example, for the cation $\mathrm{Ca}^{2+}$, the extracellular concentration lies around $1.5 \mathrm{mM}$ and the intracellular concentration of most cells is around $100 \mathrm{nM}$. According to the Nernst equation, the electrochemical potential of $\mathrm{Ca}^{2+}$,

$$
E_{k}=\frac{\mathrm{RT}}{2 \mathrm{~F}} \ln \frac{\left[\mathrm{Ca}^{2+}\right]_{o}}{\left[\mathrm{Ca}^{2+}\right]_{i}}
$$

at $37{ }^{\circ} \mathrm{C}$, is $+129 \mathrm{mV}$. Typically, a neuron has a resting transmembrane voltage at around $-70 \mathrm{mV}$, which can vary transiently during signal transmission from -90 $\mathrm{mV}$ to $\sim+60 \mathrm{mV}$. Therefore, the opening of plasma membrane calcium channels will always favour the entry of $\mathrm{Ca}^{2+}$ into the cell. While sodium and potassium channels are used mainly for signal transmission/ propagation along neuronal membranes, the $\mathrm{Ca}^{2+}$-channels are used for rapid signal transduction into the cell as well.

Voltage-gated channels open their pore as a response to a change in the transmembrane voltage. The voltage-gated calcium channels have been historically divided into high-voltage-activated (HVA) channels, which typically open when the transmembrane voltage reaches $-40 \mathrm{mV}$, and low-voltage-activated (LVA) channels, which open around $-70 \mathrm{mV}$. The LVA calcium channels are also named T-type calcium channels because their first electrophysiological identification showed that they have a Tiny conductance and produce a Transient current in comparison with the first described LVA calcium channels, the L-type calcium channels, which have a Large conductance and a Lasting current. ${ }^{[2]}$ The more modern, gene-based nomenclature identifies three distinct T-type calcium channels, which were named $\mathrm{Ca} 3.1$, $\mathrm{Ca}_{\mathrm{v}} 3.2$, and $\mathrm{Ca}_{\mathrm{v}} 3.3$ (Fig. 1). ${ }^{[3]}$ In this paper, we will use 'T-type calcium channels' when all three channels are considered, and we will use the $\mathrm{Ca}$ 3.n nomenclature when considering specific channel subtypes.

T-type calcium channels are expressed mainly in the brain and in the heart. ${ }^{[4]}$ Accordingly, drugs targeting them have been developed mainly to treat diseases linked to these organs. The first class of compounds claimed to block T-type calcium channels, exemplified by mibefradil (compound 1, Fig. 2), possess a tertiary 
amine flanked by two large, rather apolar moieties. Their pharmacological activity was discovered phenotypically, and their action on T-type calcium channel was recognized much later. Mibefradil is not selective and blocks many different types of ion channels: most voltage-gated calcium channels, ${ }^{[5]}$ sodium channels, ${ }^{[6]}$ many voltage-gated potassium channels ${ }^{[7]}$ and some chloride channels. ${ }^{[8]}$ Other compounds from a similar class showed similar potencies towards $\mathrm{Ca}_{\mathrm{v}} 3.2$ and $\mathrm{Ca}_{\mathrm{y}} 1.2$, , ${ }^{[9]}$ like verapamil (compound 2), which blocks $\mathrm{Ca} 3.1$ with potency similar to $\mathrm{Ca}_{\mathrm{v}} 1.2 .{ }^{[10]}$

The discovery of potent, selective T-type calcium channel blockers has been a matter of relatively recent research. Indeed, while high throughput screening protocols have been available for many years for more traditional targets such as GPCRs, the development of similar techniques for voltage-gated channels occurred only a few years ago. In particular, the development of FLIPR $^{\circledR}$ assays for T-type calcium channels was published rather recently. ${ }^{[11]}$ These developments have allowed the identification of a few potent, selective compounds that have already entered clinical trials. For instance, MK-8998 (compound 3) proceeded into phase 2 clinical trials for the treatment of acute psychosis in patients with schizophrenia, ${ }^{[12]}$ and Z-944 (compound 4) entered phase 1 clinical trials, presumably targeting pain as indication. ${ }^{[13]}$ More recently, CX-8998 and CX-5395 (structures unknown) were claimed to be new T-type calcium channel blockers in clinical trials. [14]

The role of T-type calcium channels in the heart has been partially elucidated using early compounds and genetically-modified animals.[15] Over the last ten years, the role of the T-type calcium channels has been evaluated in different CNS-related diseases, like epilepsy, ${ }^{[16]}$ schizophrenia,[12,17] Parkinson's disease, ${ }^{[18]}$ essential tremor, [16f,19] obesity, ${ }^{[20]}$ and pain. ${ }^{21]}$ Mutations in the genes encoding the $\mathrm{Ca}_{\mathrm{v}} 3.1$ and $\mathrm{Ca}_{\mathrm{v}} 3.2$ channels, mostly leading to a gain of function, have been linked to childhood absence epilepsy and other forms of idiopathic generalized epilepsies. ${ }^{[22]}$ Based on these observations, we decided to embark on a program directed toward the identification of potent, selective T-type calcium channel blockers for the treatment of idiopathic generalized epilepsies. Beside standard safety criteria, our objective was the discovery of a compound with an $\mathrm{IC}_{50 \text {, total in brain }}=\mathrm{IC}_{50 \text {, in vitro }} / \mathrm{f}_{\mathrm{u} \text {,brain }}$ (fraction of free to protein-bound brain concentration) not exceeding $5 \mu \mathrm{M}$, the maximum total concentration that can be anticipated for a CNS drug with a single molecular target, in our experience. The compound should be suitable for a once a day oral dosing in human. Finally, as the impact of

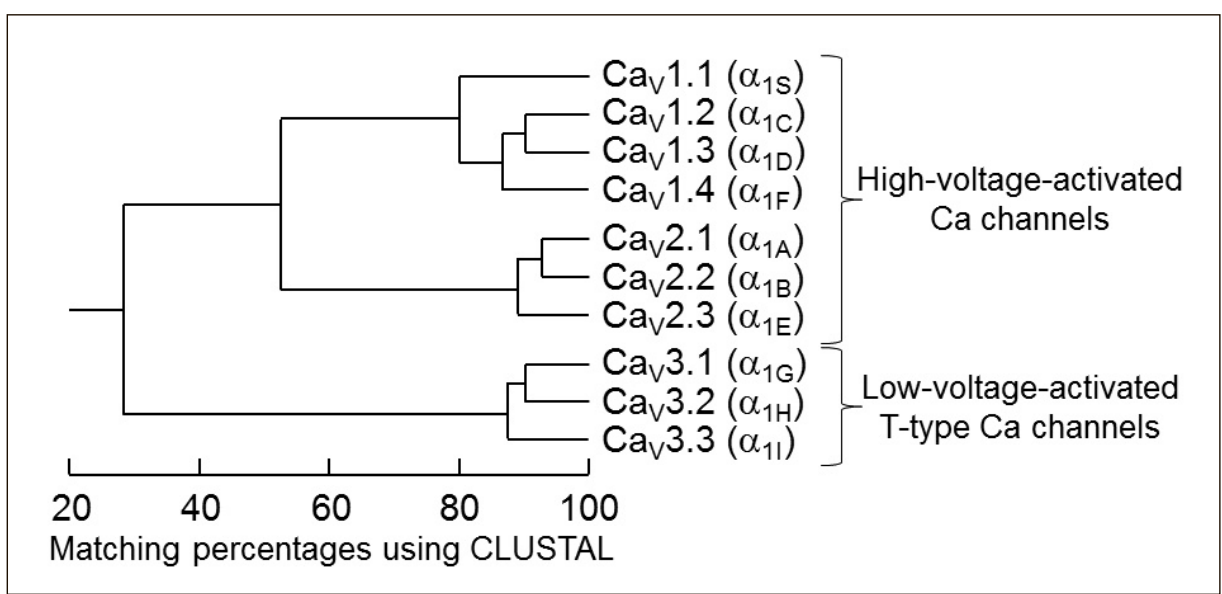

Fig. 1. Phylogeny of voltage-gated calcium channels. The sequences of the membrane-spanning segments and the pore loops of the a subunits ( 350 amino acids) are compared, which defines a subfamily of 7 high-voltage-activated $\mathrm{Ca}$ channels and another of 3 low-voltage-activated $\mathrm{Ca}$ channels. Adapted with permission from ref. [3].

Fig. 2. A few T-type calcium channel blockers.

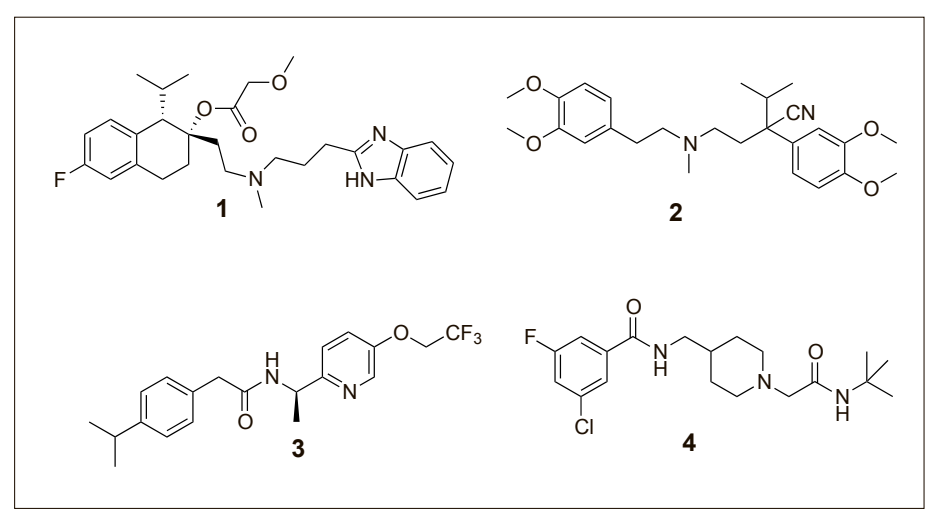

blocking only one T-type calcium channel subtype (i.e. $\mathrm{Ca}_{\mathrm{v}} 3.1, \mathrm{Ca}_{\mathrm{v}} 3.2$, or $\mathrm{Ca}_{\mathrm{v}} 3.3$ ) was not clear, we aimed for a compound that would block all three channels with similar potencies.

\section{HTS Campaign and Hit Identification}

Using the FLIPR ${ }^{\circledR}$ technique mentioned previously, an HTS campaign was initiated. A full-deck screen (around 300'000 compounds) ${ }^{[23]}$ was run on the human $\mathrm{Ca}_{\mathrm{v}} 3.2$ channel at $10 \mu \mathrm{M}$, followed by a selectivity screen on the human $\mathrm{Ca}_{v}$ 1.2-channel at the same concentration. The $\mathrm{Ca}_{\mathrm{v}} 1.2$-channel was selected as anti-target since its inhibition can lead to undesired cardiovascular side effects. Compounds showing more than $80 \%$ inhibition of $\mathrm{Ca}_{3} 3.2$ and less than $60 \%$ inhibition of $\mathrm{Ca}_{\mathrm{v}} 1.2$ were characterized with concentration-response curves on the four human channels $\mathrm{Ca}_{\mathrm{v}} 3.1$, $\mathrm{Ca}_{\mathrm{v}}$ 3.2, $\mathrm{Ca}_{\mathrm{v}} 3.3$, and $\mathrm{Ca}_{\mathrm{v}}$ 1.2. In addition, a counter screen on the hERG-channel was performed. This cascade identified a number of hits, among others the thiophene derivative $\mathbf{5}$ and the dihydropyrazole $\mathbf{6}$ (Fig. 3). These two compounds were potent $\mathrm{Ca} 3.2$ blockers (Table 1) with good ligand efficiencies (LE, 0.39 for compound 5, and 0.35 for compound 6). Compound 6 blocked the three T-type calcium channel subtypes with similar potency whereas compound 5 was less potent on $\mathrm{Ca} 3.1$ and inactive on $\mathrm{Ca}_{\mathrm{y}} 3.3$. The absence of potency of thiophene 5 on $\mathrm{Ca}_{\mathrm{v}} 3.3$ was rather unexpected, but did not prevent us from further studying this hit (vide infra).
Fig. 3. Two hits from the HTS campaign on $\mathrm{Ca}_{\text {3.2. }}$.
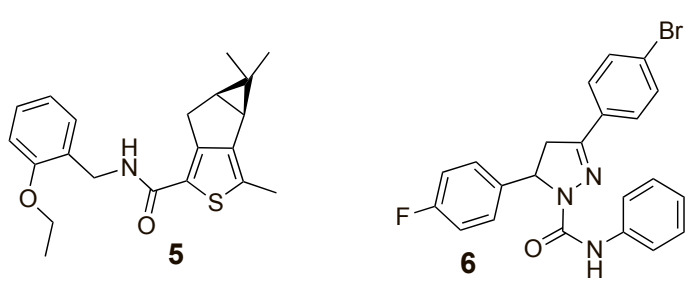
Table 1. Potencies, solubility, and efflux ratio of compounds 5-13.

\begin{tabular}{|c|c|c|c|c|c|c|}
\hline $\begin{array}{l}\text { Compound } \\
\text { number }\end{array}$ & $\begin{array}{l}\mathrm{IC}_{50} \mathrm{Ca}_{\mathrm{v}} 3.1 \\
{[\mathrm{nM}]^{\mathrm{a}}}\end{array}$ & $\begin{array}{l}\mathrm{IC}_{50} \mathrm{Ca}_{\mathrm{v}} 3.2 \\
{[\mathrm{nM}]^{\mathrm{a}}}\end{array}$ & $\begin{array}{l}\mathrm{IC}_{50} \mathrm{Ca}_{\mathrm{v}} 3.3 \\
{[\mathrm{nM}]^{\mathrm{a}}}\end{array}$ & $\begin{array}{l}\mathrm{IC}_{50} \mathrm{Ca}_{\mathrm{v}} 1.2 \\
{[\mathrm{nM}]^{\mathrm{a}}}\end{array}$ & $\begin{array}{l}\text { Sol. @ pH } 7 \\
{[\mathrm{mg} / \mathrm{L}]}\end{array}$ & $\begin{array}{l}\text { Efflux ratio } \\
\text { (Pgp) }\end{array}$ \\
\hline 5 & 870 & 78 & $>10000$ & $>10000$ & - & - \\
\hline 6 & 27 & 63 & 110 & $>10000$ & - & - \\
\hline 7 & 26 & 31 & 330 & 6200 & 2 & 1.0 \\
\hline 8 & 530 & 220 & 1200 & $>10000$ & 25 & 104 \\
\hline 9 & 84 & 120 & 250 & $>10000$ & & \\
\hline$(R)-9$ & 45 & 30 & 56 & 4800 & & \\
\hline$(S)-9$ & $>10000$ & $>10000$ & $>10000$ & - & & \\
\hline 10 & 200 & 6.6 & 740 & 2700 & $<1$ & - \\
\hline 11 & $>10000$ & 33 & $>10000$ & $>10000$ & $<1$ & - \\
\hline 12 & 160 & 5000 & $>10000$ & $>10000$ & - & - \\
\hline 13 & 140 & 100 & 11 & $>10000$ & 27 & - \\
\hline
\end{tabular}

${ }^{\mathrm{a}} \mathrm{Geo}$ mean of at least two measurements

\section{The Dihydropyrazoles}

Simple modifications on dihydropyrazole 6 rapidly led to potent T-type calcium channel blockers. ${ }^{[16 b]}$ In particular, introduction of a second para-fluoro substituent and replacement of a para-bromophenyl by a 4-pyridinyl led to compound 7 (Fig. 4, Table 1) that was potent enough for complete characterization. In particular, this compound was not a substrate for P-glycoprotein (Pgp), which are efflux pumps that prevent many compounds from penetrating into the brain, and its pyridinyl moiety facilitated its formulation for in vivo studies. When this compound was administered orally at a dose of $100 \mathrm{mg} /$ $\mathrm{kg}$ to Wistar Albino Glaxo Rats of Rijswijk (WAG/Rij rats), a model of generalized absence-like epilepsy, ${ }^{[24]}$ a complete suppression of the spontaneous seizures was observed for $4 \mathrm{~h}$ and a reduction in their incidence for the following $7 \mathrm{~h}$ (Fig. 5a). Over the $12 \mathrm{~h}$ period following administration, the cumulative duration of seizures was decreased by $58 \%$ compared to vehicle-treated rats (Fig. $5 b ; p=0.013$, paired t-test). In spite of this promising result, dihydropyrazole 7 (as well as many compounds from this series) suffered from high clearance in rats and rather poor solubility in aqueous buffer at $\mathrm{pH}$ 7. Attempts to solve these issues by introducing more polarity on a fairly large, lipophilic template, led for instance to dihydropyrazole 8. The introduction of more polar moieties resulted, as expected, in an improved aqueous solubility but compound $\mathbf{8}$ was

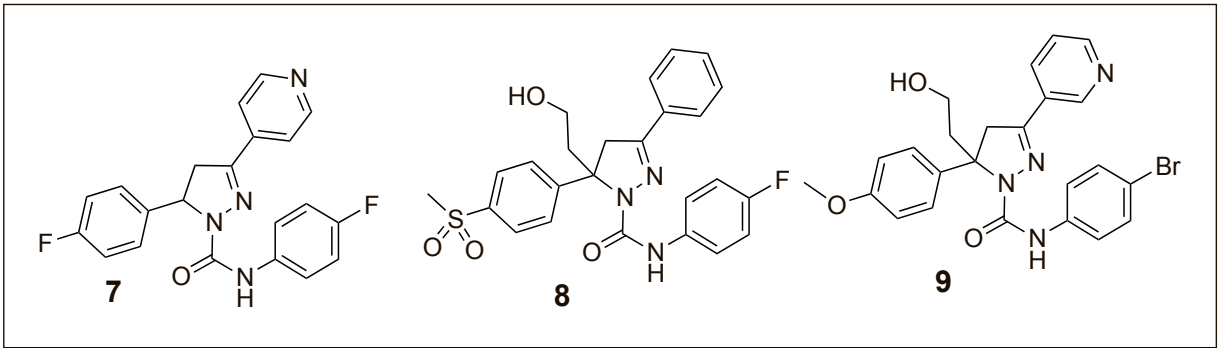

Fig. 4. Dihydropyrazoles 7-9.

slightly less biologically active and was a Pgp substrate (Table 1). It should be noted that compounds 6-8 were prepared and studied as racemates. Later on, compound 9 was prepared, its enantiomers were separated by HPLC using a chiral stationary phase, and the absolute configuration of compound $(S)-9$ was determined by X-ray structure analysis. Testing both enantiomers $(R)-9$ and $(S)$-9 showed that the $(R)$ enantiomer is responsible for blocking the T-type calcium channels (Table 1). Despite considerable efforts, we were not able to fine-tune this series of dihydropyrazoles and to identify compounds with a good balance of potency, solubility, active efflux, and clearance.

Compound 7 was nevertheless a reasonable model compound and it was used to evaluate the cardiovascular actions of our T-type calcium channel blockers. These actions were evaluated in freely-moving, conscious male spontaneously hypertensive rats (SHRs, Wistar-Kyoto background) equipped with a telemetry system allowing non-invasive monitoring of mean arterial pressure (MAP), heart rate (HR) and electrocardiogram. Compound 7 administered as a single oral dose of 100 $\mathrm{mg} / \mathrm{kg}$ decreased MAP $12 \mathrm{mmHg}$ (return to baseline within 18 h, Fig. 6A), decreased HR slightly (return to baseline within $6 \mathrm{~h}$, not shown), and it increased the PR-interval of the ECG, indicative of AV-block type I (return to baseline within $10 \mathrm{~h}$, Fig. 6B). Compound 7 also induced a very low incidence of AV-blocks type II (Wenckebach and Mobitz II). Reference T-type calcium channel blockers (e.g. compound 3 ) were also tested in this animal model, which showed that the observed PR-interval prolongation was probably target related, i.e. linked to the blockade of the T-type calcium channels. From these observations, safety concerns arose regarding T-type calcium channels as a target for a neurological disease. Since our compounds blocked the three T-type calcium channel subtypes, an obvious question was whether the desired antiepileptic effect and the undesired PRprolongation might be dissociated using subtype-specific blockers. 


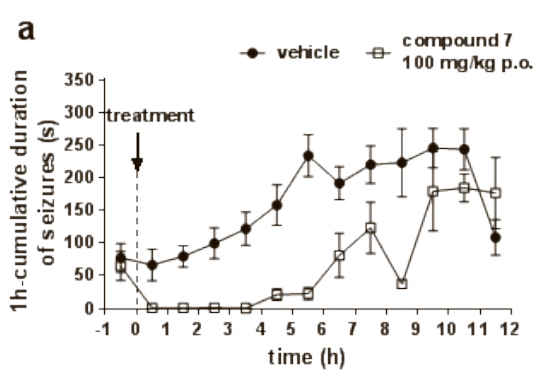

C

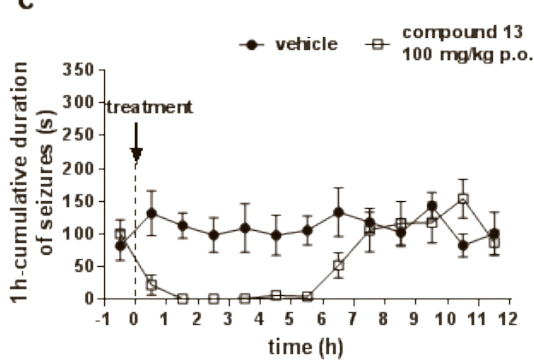

e

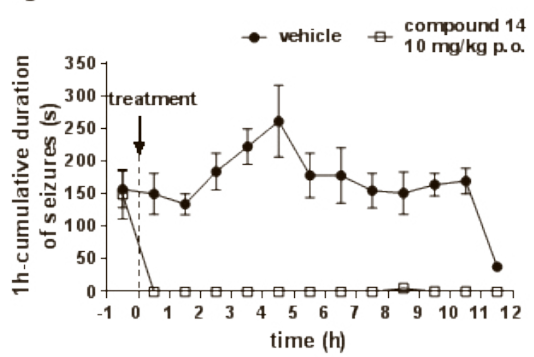

g

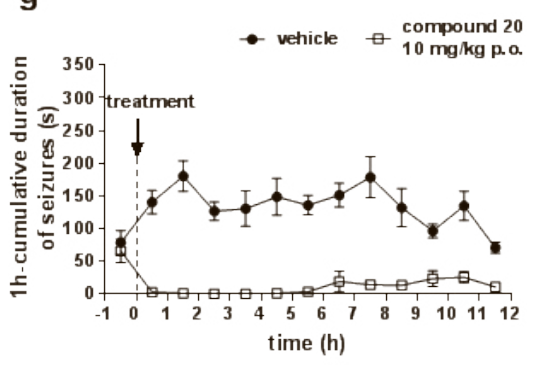

b

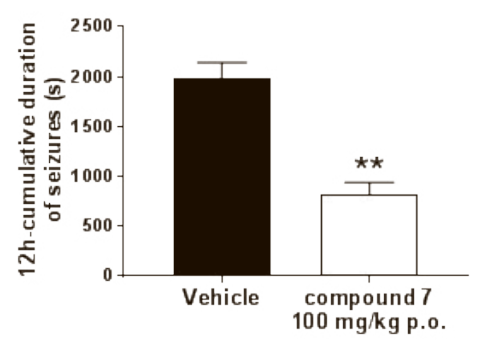

d

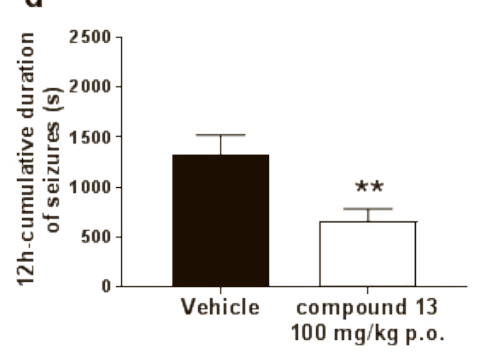

$\mathbf{f}$

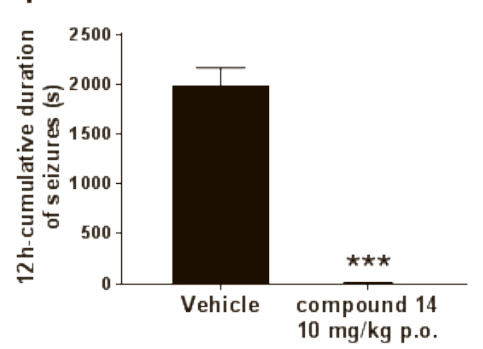

h

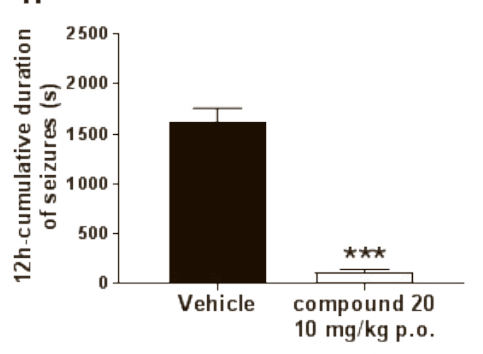

Fig. 5. Impact of compound 7, 13, 14 or 20 on spontaneous absence seizures in male WAG/ Rij rats. The cumulative duration of seizures is expressed as mean \pm SEM per hour (a, c, e, g for compound 7, 13, 14 and 20 respectively) or over the $12 \mathrm{~h}$ night period following administration (b, d, f, h for compound 7, 13, 14 and 20 respectively), $n=7-8$ per group. ${ }^{\star *}, p<0.01 ;{ }^{* *}, p<0.001$ compared to vehicle treated rats (paired t-test). p.o., per os

\section{The Subtype-selective Blockers}

As noted earlier thiophene derivative 5 did not block $\mathrm{Ca}_{\mathrm{y}} 3.3$ and had different potencies for $\mathrm{Ca}_{\mathrm{v}} 3.1^{\mathrm{v}}$ and $\mathrm{Ca} 3.2$. This was a first hint at a possible identification of subtype-selective blockers. During SARstudies around thiophene $\mathbf{5}$, aiming at simplifying the structure and at reducing its lipophilicity, we discovered pyrroles 10 and 11 (Fig. 7, Table 1), which were potent and highly selective $\mathrm{Ca}_{\mathrm{v}} 3.2$ blockers. ${ }^{[25]}$ Furthermore, changing the pyrrole moiety for a pyrazole core and optimizing the different exit vectors led to compound 12, which was a somewhat selective $\mathrm{Ca}_{\mathrm{v}} 3.1$ blocker. [26] Unfortunately, these compounds had poor physicochemical properties, especially solubility, and extremely low levels of free (protein-unbound) brain concentrations. Consequently, even when administered orally to rats at $100 \mathrm{mg} / \mathrm{kg}$, in vivo unbound concentrations remained below the lowest $\mathrm{IC}_{50}$-value, preventing us from reaching any conclusion regarding the efficacy and safety of subtype-selective blockers. Alternatively, these compounds could be useful for in vitro studies, and might contribute to a better understanding of the specific roles of $\mathrm{Ca}_{\mathrm{v}} 3.1$ and $\mathrm{Ca}_{\mathrm{v}} 3.2$.

Later on, we discovered benzodiazepine derivatives with a moderate selec- tivity toward $\mathrm{Ca} 3.3$, such as compound 13. ${ }^{[16 a]}$ Compound 13, when administered orally at $100 \mathrm{mg} / \mathrm{kg}$, decreased by $50 \%$ the cumulative duration of seizures in the WAG/Rij rat model $(\mathrm{p}=0.017$ compared to vehicle-treated rats, paired t-test; Fig. $5 \mathrm{c}$ and $5 \mathrm{~d}$ ). This effect was observed at an unbound brain concentration expected to block only $\mathrm{Ca}_{\mathrm{v}} 3.3$. Considering carefully the pharmacokinetic-pharmacodynamics relationship of compound $\mathbf{7}$, described earlier, it has to be noticed that efficacy was observed at concentrations expected to block only $\mathrm{Ca}_{\mathrm{v}} 3.1$ and $\mathrm{Ca}_{\mathrm{v}} 3.2$. If this is the case, this would indicate that blocking all three T-type calcium channels is not necessary in the WAG/Rij rat model to suppress seizures.

\section{The Aminopyrazoles}

As noted, subtype-selective blockers were identified but generally these compounds did not display drug-like properties. Meanwhile, we had made some progress in understanding the observed PR-prolongation. First, we realized that increasing the administered dose increased $\mathrm{C}_{\max }$ and $\mathrm{AUC}_{0-24 \mathrm{~h}}$ but it did not lead to increased magnitude of PR-prolongation, only to increased duration of the effect. Consistent with this observation, we also never detected more advanced AV-blocks, such as type III AV-blocks. Second, we realized that PR-prolongation was observed in rats and mice only but never in guinea pigs, dogs or monkeys at similar exposures. This was consistent with the published data on compound $\mathbf{3}$, which did not prolong the PR-interval in dogs or humans (no published data on rats). Therefore, we decided that PR-prolongation in rodents should not prevent us from developing a new drug for human use and we came back to triple blockers. While developing the structure-activity relationship (SAR) around the pyrazole template, ${ }^{[27]}$ aminopyrazole amides were identified as a low molecular weight, very potent triple blocker (Fig. 8 and Table 2). Compound 14 displayed a ligand efficiency of 0.43 and a lipophilic ligand efficacy of 5.8, on $\mathrm{Ca}_{\mathrm{v}} 3.2$, excellent for a lead compound. ${ }^{[28]}$ In the WAG/Rij rat model, a sustained efficacy was achieved at the low dose of $10 \mathrm{mg} / \mathrm{kg}$ with suppression of seizures for $12 \mathrm{~h}(\mathrm{p}<0.001$, paired t-test; Fig. 5e and f). However, compound 14 had issues as well. First, we easily replaced the dimethylamino moiety by an isopropyl substituent (compound 15). In terms of SAR, para substituents at both phenyl rings of this type of compound were essential for potency, as can be concluded from compounds 16-18 (Table 2). On the other hand, the fairly poor solubility in aqueous buffer at $\mathrm{pH} 7$ of compound $\mathbf{1 4}$ was reduced in derivatives $\mathbf{1 5}$ and 18, an issue that had 
to be addressed to facilitate formulation purposes. Solubility in fed state simulated intestinal fluid (FeSSIF) remained acceptable, though (23 and $25 \mathrm{mg} / \mathrm{L}$, respectively). Over the course of lead optimization of the aminopyrazole class, it was found that alkoxy para-substituents (adding polarity) or groups containing fluorine atoms (probably preventing a too tight packing) were tolerated and would lead to more soluble compounds (vide infra). We also discovered that the amide bond of compound 14 was slowly hydrolysed in rat and mouse plasma $(83 \%$ and $42 \%$, respectively, of parent compound remaining after $4 \mathrm{~h}$ ). While this slow hydrolysis did not represent a dramatic clearance issue per se, it released an aminopyrazole as metabolite; a bacterial reverse mutation Ames test on (3,4-difluorobenzyl)-1H-pyrazol-3-amine (compound 19a, vide infra) was showed to be positive.

The Ames test, ${ }^{[29]}$ named after its creator, represents the most predictive assay to assess potential mutagenic carcinogenicity of organic entities. A positive Ames test does not represent a proof of mutagenicity per se, but requires extensive in vitro and in vivo studies to definitely assess mutagenic properties of the tested compound. In short, this test uses five Salmonella typhimurium bacterial strains that carry different mutations in the histidine locus, responsible for histidine synthesis. These strains (e.g. TA98, TA100, TA102, TA1535, and TA1537) cannot synthesise histidine and are auxotrophic to this amino acid. The Ames reverse mutation assay determines the frequency at which an agent can reverse or suppress the effect of the detrimental mutations, making one or more strains capable of synthesizing histidine and developing colonies on histidine-deficient culture plates. Revertant colonies are counted and compared to the number of spontaneous revertant colonies on solvent control plates. A test agent is considered positive if the number of revertant colonies exceeds the threshold of twice (for strains TA 98, TA 100, and TA 102) or thrice (for strains TA 1535 and TA 1537) the colony count in the corresponding solvent control, in any incubation. For some compounds, the metabolites rather than the parent compound can be potentially mutagenic. This is the case for aromatic amines, where the amine itself is Ames negative, but its corresponding $O$-acetyl$\mathrm{N}$-phenylhydroxylamine or $\mathrm{O}$-sulfate- $\mathrm{N}$ hydroxylamine might result in a positive Ames test. ${ }^{[30]}$ Due to the limited metabolic capacity of this bacterial system, and in order to assess the potential mutagenicity of possible metabolites, the Ames test can be conducted in absence and in presence of an exogenous metabolic acti-

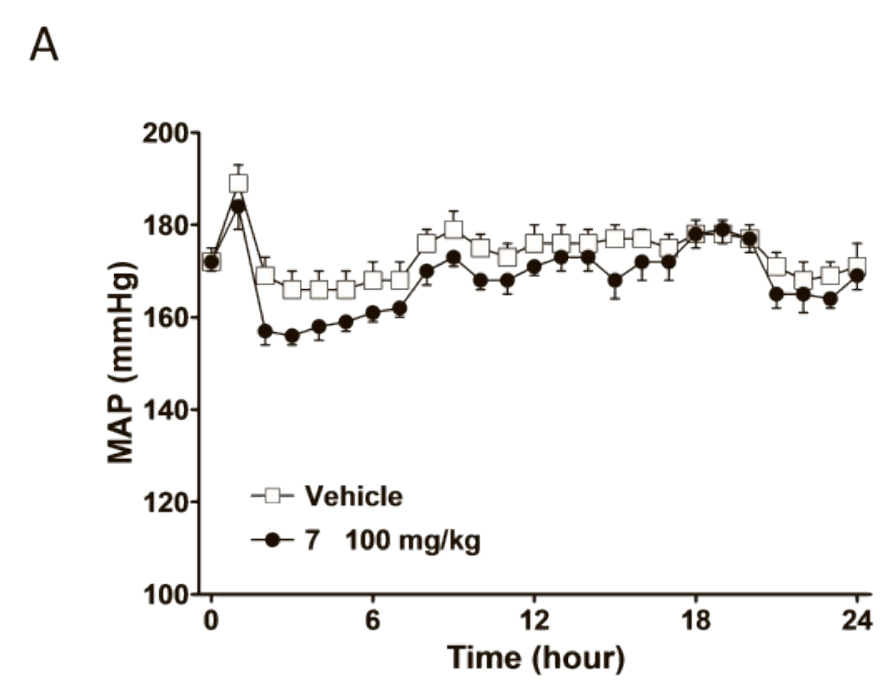

B

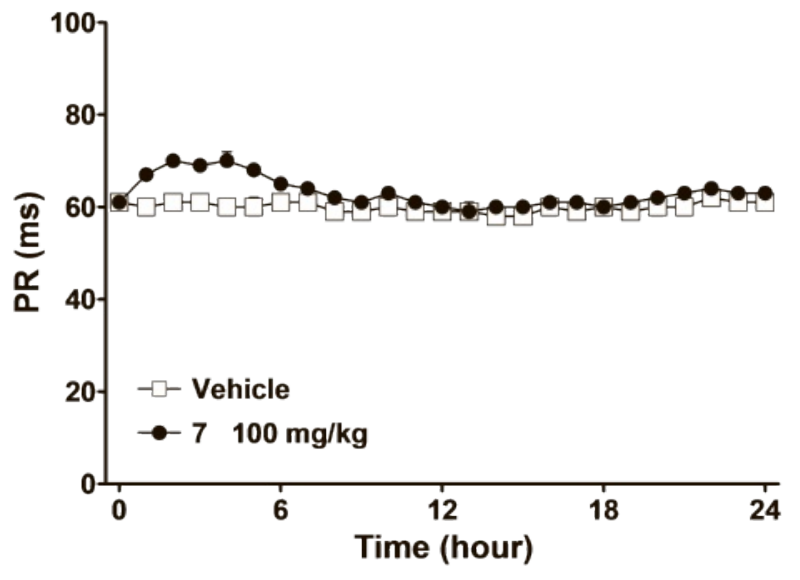

Fig. 6. Effect of oral administration of $100 \mathrm{mg} / \mathrm{kg}$ of compound $\mathbf{7}(\bullet)$ or vehicle $(\square)$ on mean arterial pressure (A) and PR-intervals (B) in conscious freely moving male spontaneous hypertensive rats. Compound or vehicle was given at time 0 and data are represented as mean \pm SEM $(n=8$ per group).<smiles>CC(C)OCc1ccccc1CNC(=O)c1c2c(c(Cl)n1C)CC(C)(C)CC2</smiles><smiles>Cn1c(C(=O)NCc2ncccc2OCC(F)(F)F)c2c(c1C(F)(F)F)CC(C)(C)CC2</smiles><smiles>O=C(NCc1ccccc1OCC(F)(F)F)c1nn(-c2ccc(F)cc2)c(-c2ccccc2)c1CF</smiles><smiles>C[C@H]1CN(Cc2ccccc2)c2cnccc2[C@@H](C)N1C(=O)NCc1ccccc1</smiles>

Fig. 7. Subtypeselective Ca-blockers 10-13. vation system, such as the phenobarbital/ beta-naphthoflavone induced rat liver S9 fraction. In the case of aromatic amines, a positive Ames test is usually observed with the TA98 and/or TA100 strains, in presence of the S9-fraction.

To avoid any risk of mutagenicity, many derivatives were prepared, and screened in an Ames test including the TA98- and TA100- strains with the S9 fraction with the goal to identify Ames negative aminopyrazoles. Keeping in mind that para-substituents on the benzyl group were essential for potency, we limited ourselves to this sub-class. In particular, we screened aminopyrazoles 19a-19g (Fig. 9, Table 3). 
Fig. 8. Aminopyrazole amides 14-22.

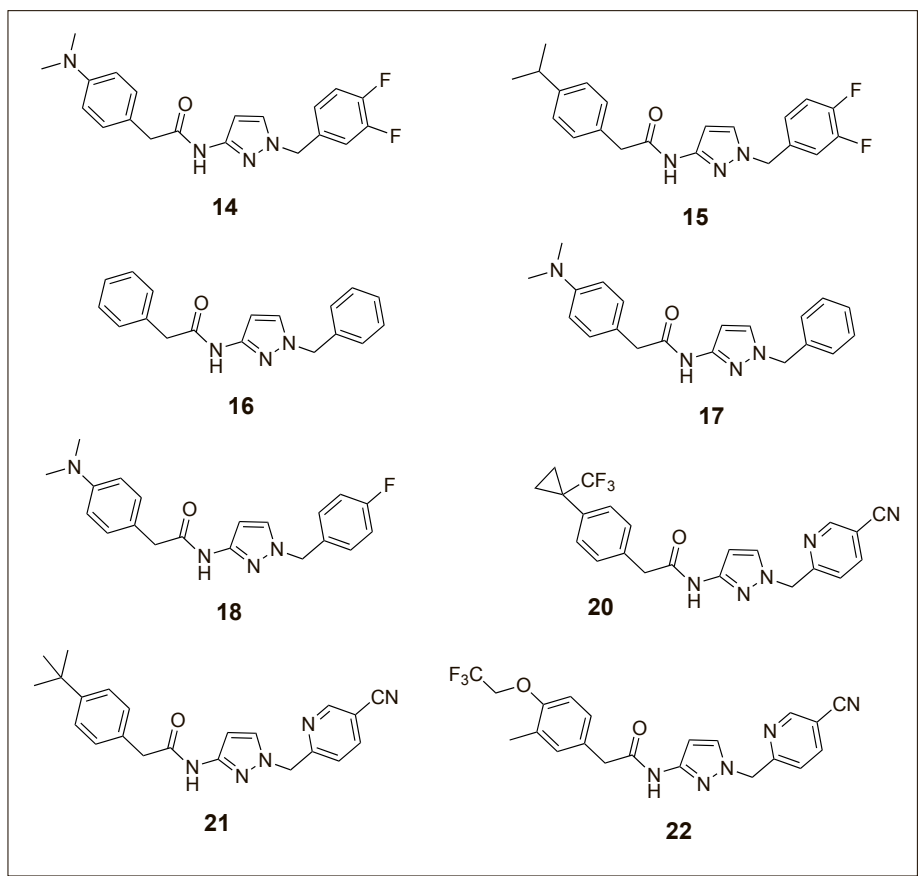

This table shows that minor modifications at a site remote from the responsible amino moiety leads to huge differences in the response of these compounds in the Ames test. It must be kept in mind that the oxidative metabolism that has to happen in CYP-enzymes can occur at multiple sites on the substrate, so that the introduction of a remote substituent might modulate dramatically the amount of oxidation at the amine itself. In such a complex process, we were not able to detect any evident SAR. The only trend was a correlation with polarity: more polar aminopyrazole derivatives, that would probably have a lower affinity for the CYP-enzymes, tended to be less prone to oxidation to the hydroxylated species mentioned above. Eventually, by trial-and-error, we identified the ami- nopyrazoles $\mathbf{1 9 f}$ and $\mathbf{1 9 g}$ as Ames negative compounds. Aminopyrazole 19g, with its 2-pyridinyl group, led to final amide compounds that tended to be more soluble. For this reason, further efforts focused on this aminopyrazole.

Among compounds containing the aminopyrazole 19g, we identified derivative 20, with an apolar trifluoromethylcyclopropyl substituent at the phenacetyl moiety (Fig. 8). This moiety, presented in the literature as a metabolically stable isostere for the tert-butyl substituent, [31] was introduced here mainly because it slightly increased the aqueous solubility of the final compound. Even more, we observed decent solubilities in fasted-state and fed-state simulated intestinal fluid (103 and $104 \mathrm{mg} / \mathrm{L}$, respectively). On the other hand, the corresponding tert-butyl derivative 21 was virtually insoluble at $\mathrm{pH}=7$ and less soluble in the simulated intestinal fluids (52 and $27 \mathrm{mg} / \mathrm{L}$ respectively). Aryl ethers, like compound 22, were much more soluble in aqueous media but turned out to be Pgp-substrates, less favourable for further development. In contrast, compound 20 proved to be only a weak Pgp-substrate and had an excellent permeability ( $\mathrm{P}$ $=54 \cdot 10^{-6} \mathrm{~cm} / \mathrm{s}, \mathrm{P}_{\text {appA } \rightarrow \mathrm{B}}=18 \cdot 10^{-6} \mathrm{~cm} / \mathrm{s}$, ratio $=3$ ). The compound was metabolically very stable (intrinsic clearance of 6 and 24 $\mu \mathrm{L} / \mathrm{min} / \mathrm{mg}$ protein in human and rat microsomes, respectively), which translated into an in vivo clearance of $24 \mathrm{~mL} / \mathrm{min} / \mathrm{kg}$ in the rat. In the WAG/Rij rat model, an oral dose of $10 \mathrm{mg} / \mathrm{kg}$ of compound $\mathbf{2 0} \mathrm{de}$ creased by $93 \%$ the cumulative duration of seizures over the $12 \mathrm{~h}$ period following oral administration, compared to vehicle-treated rats $(\mathrm{p}<0.0001$, paired t-test; Fig. $5 \mathrm{~g}$ and $5 \mathrm{~h}$ ). In the audiogenic seizure-sensitive juvenile DBA/2J mouse model of generalized convulsive seizures, ${ }^{[32]}$ a reduction of seizure severity was observed, albeit at a much higher exposure (Fig. 10). While full efficacy was observed in the WAG/Rij rat model at free brain concentrations corresponding to the $\mathrm{IC}_{50}$-value on $\mathrm{Ca}_{\mathrm{v}} 3.2$ (the T-type calcium channel for which compound 20 shows the least potency), about 15-fold higher concentrations were necessary in the mouse model; the reason for this difference is not known. Compound 20 proved to be the best-balanced compound, with an acceptable solubility profile, modest efflux, and excellent potency and efficacy in the WAG/Rij rat model. With a low intrinsic clearance in human, in rat (vide supra), and in $\operatorname{dog}(3 \mu \mathrm{L} / \mathrm{min} /$ mg protein), and with an unbound fraction of 0.024 in human plasma and of 0.014 in rat brain homogenate, this compound

Table 2. Potencies, solubility, and efflux ratio of aminopyrazole amides 14-18 and 20-22.

\begin{tabular}{|c|c|c|c|c|c|c|}
\hline $\begin{array}{l}\text { Compound } \\
\text { number }\end{array}$ & $\begin{array}{l}\mathrm{IC}_{50} \mathrm{Ca}_{\mathrm{v}} 3.1 \\
{[\mathrm{nM}]^{\mathrm{a}}}\end{array}$ & $\begin{array}{l}\mathrm{IC}_{50} \mathrm{Ca}_{\mathrm{v}} 3.2 \\
{[\mathrm{nM}]^{\mathrm{a}}}\end{array}$ & $\begin{array}{l}\mathrm{IC}_{50} \mathrm{Ca}_{\mathrm{v}} 3.3 \\
{[\mathrm{nM}]^{\mathrm{a}}}\end{array}$ & $\begin{array}{l}\mathrm{IC}_{50} \mathrm{Ca}_{\mathrm{v}} 1.2 \\
{[\mathrm{nM}]^{\mathrm{a}}}\end{array}$ & $\begin{array}{l}\text { Sol. @ pH } 7 \\
{[\mathrm{mg} / \mathrm{L}]}\end{array}$ & $\begin{array}{l}\text { Efflux ratio } \\
\text { (Pgp) }\end{array}$ \\
\hline 14 & 1.5 & 3.4 & 0.89 & 7100 & 3 & 0.9 \\
\hline 15 & 1.4 & 6.0 & 1.8 & 1540 & $<1$ & - \\
\hline 16 & 1140 & $>10000$ & 390 & - & - & - \\
\hline 17 & 14 & 38 & 2.9 & $>10000$ & 3 & 1.0 \\
\hline 18 & 4.2 & 12 & 2.0 & $>10000$ & 1 & - \\
\hline 20 & 6.4 & 18 & 7.5 & 2410 & 5 & 3 \\
\hline 21 & 2.8 & 7.5 & 2.6 & 2420 & $<1$ & - \\
\hline 22 & 2.2 & 7.0 & 1.7 & 3310 & 25 & 4.5 \\
\hline
\end{tabular}

${ }^{\mathrm{a}}$ Geo mean of at least two measurements 


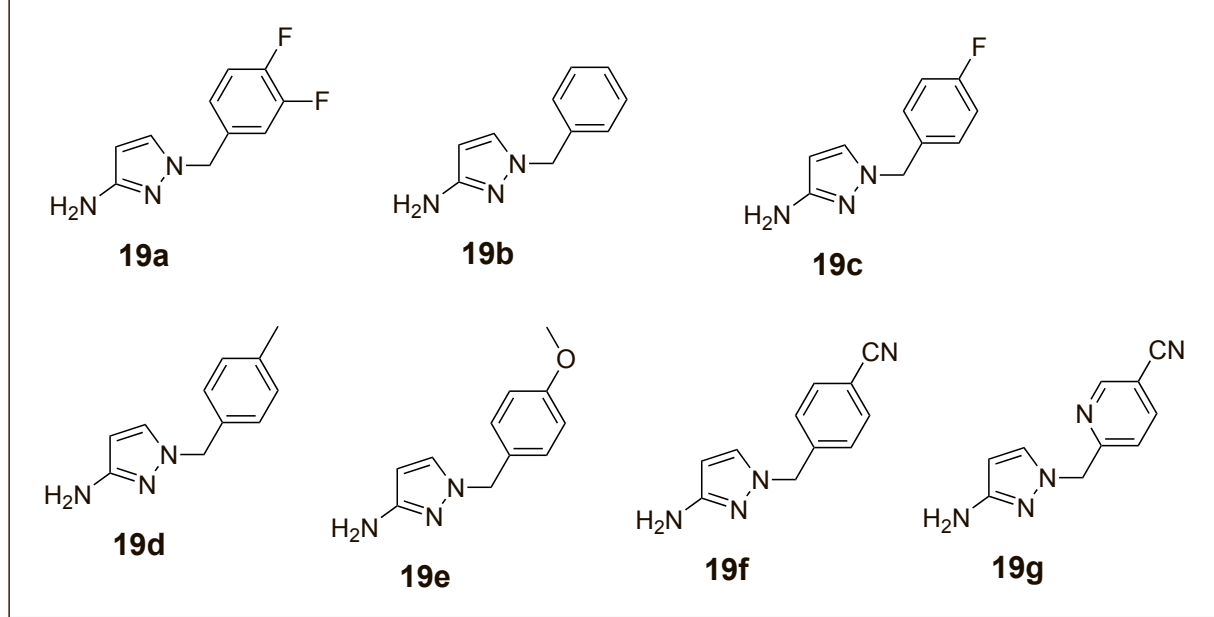

Fig. 9. A few representative aminopyrazoles.

Table 3. Ames test for different aminopyrazoles

\section{Compound number}

Fold increase $^{\mathrm{a}}$

TA98 + S9

$$
2.7
$$

4.1

15.1

19d

$$
8.0
$$

1.0

19f

$19 \mathrm{~g}$

\section{Fold increase ${ }^{\mathrm{a}}$}

TA100 + S9

1.2

30.3
${ }^{a}$ Highest fold over full range of compound concentrations

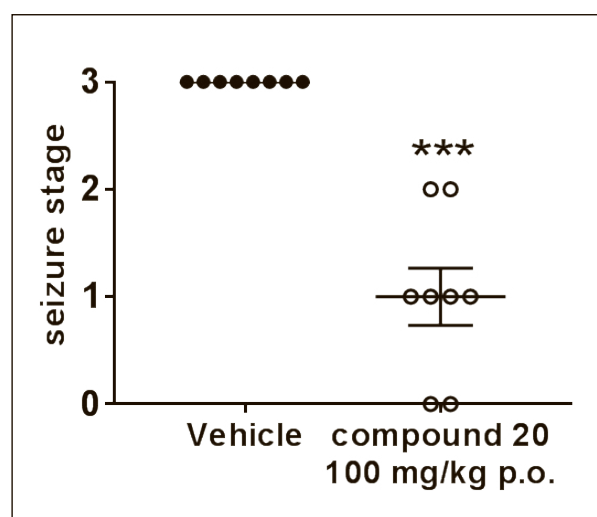

Fig. 10. Impact of compound $\mathbf{2 0}$ on seizure severity in the audiogenic seizure-sensitive juvenile DBA/2J mouse model $3 \mathrm{~h}$ post administration. Data are expressed as mean \pm SEM, $\mathrm{n}=8-10$ per group. In the mouse model, seizure stage $0=$ normal behavior, $1=$ wild running, $2=$ clonic seizure and $3=$ tonic exension of the hind limbs. ${ }^{* \star *}, p<0.001$ compared to vehicle treated animals (Mann-Whitney test ). p.o., peros. was predicted to be suitable for once-aday dosing in human. It was shown to be negative in the Ames test and presented an excellent safety profile in vivo and in vitro, which led to its selection as a preclinical candidate.

\section{Conclusion}

In conclusion, our effort started from dihydropyrazole derivatives, which were rapidly optimized in terms of potency and allowed us to generate a first positive in vivo proof of concept for T-type calcium channel blockers for generalized epilepsies. However, we also observed a prolongation of the PR-interval in rodents, making us investigate subtype-selective T-type calcium channel blockers. Although selective compounds were identified, in particular for $\mathrm{Ca}_{\mathrm{v}} 3.2$, these compounds had poor physicochemical properties and were not suitable for further development. Discarding the PR-prolongation issue as not human-relevant, we proceeded to a series of non-subtype-selective aminopyrazole amides, whose drug-like properties were rapidly enhanced. The optimization of the aminopyrazole moiety, in order to avoid an Ames positive, potential metabolite, and a fine balance between physicochemical and metabolic properties led to the identification of compound $\mathbf{2 0}$ as a preclinical candidate.

\section{Acknowledgements}

Martin Faes, Sophie Moujon, Dominik Juchli, Daniel Hafner, Alice Prudhomme, Claire Hinder, Sven Glutz, Elodie Kérivel, Aude Bauer, Gaël Jacob, Janine Hotz, Siefke Siefken, Viktor Ribic, Lise-May Viment, Christine Berthion, Hélène Roellinger, Hélène Massinet, Eileen Hubert, Célia Mueller, Jacques Mawet, Daniel Wanner and Céline Bortolamiol, Romain Sube, Camille Forny, Marion Aubert, Alexander Hasler, Julia Friedrich, Nathalie Jaouen, Eric Soubieux, Michel Rauser, Isabelle Weber, Aude Weigel and Rolf Wuest are thanked for their dedication and experimental contribution.

Received: August 14, 2017

[1] a) D. S. Stetson, J. W. Albers, B. A. Silverstein R. A. Wolfe, Muscle and Nerve 1992, 15, 1095; b) B. L. Andrew, N. J. Part, Q. J. Exp. Physiol. Cogn. Med. Sci. 1972, 57, 213; c) M. J. Sedano, A. Canga, C. de Pablos, J. M. Polo, J. Berciano, J. Neurol. 2013, 260, 1624.

[2] M. C. Nowycky, A. P. Fox, R. W. Tsien, Nature 1985, 316, 440

[3] E. A. Ertel, K. P. Campbell, M. M. Harpold, F. Hofmann, Y. Mori, E. Perez-Reyes, A. Schwartz, T. P. Snutch, T. Tanabe, L. Birnbaumer, R. W. Tsien, W. A. Catterall, Neuron 2000, 25, 533.

[4] G. W. Zamponi, J. Striessnig, A. Koschak, A.C. Dolphin, Pharmacol Rev 2015, 67, 821.

[5] I. Bezprozvanny, R. W. Tsieng, Mol. Pharmacol. 1995, 48,540

[6] M. M. McNulty, D. A. Hanck, Mol. Pharmacol. 2004, 66, 1652

[7] a) C. Chouabe, M. D. Drici, G. Romey, J. Barhadin, M. Lazdunski, Mol. Pharmacol. 1998, 54, 695; b) J. H. Liu, P. Bijlenga, T. Occhiodoro, J. Fischer-Lougheed, C. R. Bader, L. Bernheim, Br. J. Pharmacol. 1999, 126, 245; c) L. Perchenet, O. Clement-Chomienne, J. Pharmacol. Exp. Ther. 2000, 295, 771; d) J. C. Gomora, J. A. Enyeart, J. J. Enyeart, Mol. Pharmacol. 1999, 56, 1192.

[8] B. Nilius, J. Prenen, M. Kamouchi, F. Viana, T. Voets, G. Droogmans, Br. J. Pharmacol. 1997, $121,547$.

[9] D. Renneberg, F. Hubler, M. Rey, P. Hess, S. Delahaye, J. Gatfield, M. Iglarz, K. Hilpert, Bioorg. Med. Chem. Lett. 2015, 25, 3941.

[10] B. S. Freeze, M. M. McNulty, D. A. Hanck, Mol. Pharmacol. 2006, 70, 718 .

[11] a) X. Xie, A. L. van Deusen, I. Vitko, D. A. Babu, L. A. Davies, N. Huynh, H. Cheng, N. Yang, P. Q. Barrett, E. Perez-Reyes, Assay Drug Dev. Technol. 2007, 5, 191; b) F. Belartelli, E. Tringham, C. Eduljee, X. Jiang, H. Dong, A. Hendricson, Y. Shimizu, D. L. Janke, D. Parker, 
J. Mezeyova, A. Khawaja, H. Pajoulesh, R. A Fraser, S. P. Arneric, T. P. Snutch, Assay Drug Dev. Technol. 2009, 7, 266.

[12] M. F. Egan, X. Zhao, A. Smith, M. D. Troyer, V. N. Uebele, V. Pidkorytov, K. Cox, M. Murphy, D. Snavely, C. Lines, D. Michelson, Hum Psychopharmacol. 2013, 28, 124.

[13] G. W. Zamponi, Nat. Rev. Drug Discov. 2016, $15,19$.

[14] http://cavionpharma.com/technology-and-platform

[15] a) L. Cribbs, Channels (Austin) 2010, 4, 447, b) P. Mesirca, A. G. Torrente, M. E. Mangoni, Front. Physiol. 2015 6, 19.

[16] a) R. Siegrist, D. Pozzi, G. Jacob, C. Torrisi, K. Colas, B. Braibant, J. Mawet, T. Pfeifer, R. de Kanter, C. Roch, M. Kessler, O. Corminboeuf, O. Bezencon, J. Med. Chem. 2016, 59, 10661 b) L. Remen, O. Bezencon, L. Simons, R. Gaston, D. Downing, J. Gatfield, C. Roch, M Kessler, J. Mosbacher, T. Pfeifer, C. Grisostomi, M. Rey, E. A. Ertel, R. Moon, J. Med. Chem. 2016, 59, 8398; c) W. D. Shipe, J. C. Barrow, Z. Q. Yang, C. W. Lindsley, F. V. Yang, K. A Schlegel, Y. Shu, K. E. Rittle, M. G. Bock, G D. Hartman, C. Tang, J. E. Ballard, Y. Kuo, E. D. Adarayan, T. Prueksaritanont, M. M. Zrada, V. N. Uebele, C. E. Nuss, T. M. Connolly, S. M Doran, S. V. Fox, R. L. Kraus, M. J. Marino, V K. Graufelds, H. M. Vargas, P. B. Bunting, M. Hasbun-Manning, R. M. Evans, K. S. Koblan, J. J. Renger, J. Med. Chem. 2008, 51, 3692; d) E. Tringham, K. L. Powell, S. M. Cain, K. Kuplast, J. Mezeyova, M. Weerapura, C. Eduljee, X Jiang, P. Smith, J. L. Morrison, N. C. Jones, E. Braine, G. Rind, M. Fee-Maki, D. Parker, H. Pajouhesh, M. Parmar, T. J. O'Brien, T. P Snutch, Sci. Transl. Med. 2012, 4, 121; e) P. M Casillas-Espinosa, A. Hicks, A. Jeffreys, T. P Snutch, T. J. O'Brien, K. L. Powell, PLoS One 2015, 10, e0130012; f) Z. Q. Yang, J. C. Barrow, W. D. Shipe, K. A. Schlegel, Y. Shu, F. V. Yang, C. W. Lindsley, K. E. Rittle, M. G. Bock, G. D Hartman, V. N. Uebele, C. E. Nuss, S. V. Fox, R. L. Kraus, S. M. Doran, T. M. Connolly, C. Tang, J. E. Ballard, Y. Kuo, E. D. Adarayan, T Prueksaritanont, M. M. Zrada, M. J. Marino, V K. Graufelds, A. G. DiLella, I. J. Reynolds, H M. Vargas, P. B. Bunting, R. F. Woltmann, M.
M. Magee, K. S. Koblan, J. J. Renger, J. Med. Chem. 2008, 51, 6471.

[17] J. M. Uslaner, S. M. Smith, S. L. Huszar, R. Pachmerhiwala, R. M. Hinchliffe, J. D. Vardigan, S. J. Nguyen, N. O. Surles, L. Yao, J. C. Barrow, V. N. Uebele, J. J. Renger, J. Clark, P. H. Hutson, Neuropharmacology 2012, 62, 1413.

[18] a) Y. C. Yang, C. H. Tai, M. K. Pan, C. C. Kuo, Pflugers Arch. 2014, 466, 747; b) Z. Xiang, A. D. Thompson, J. T. Brogan, M. L. Schulte, B. J. Melancon, D. Mi, L. M. Lewis, B. Zou, L. Yang, R. Morrison, T. Santomango, F. Byers, K. Brewer, J. S. Aldrich, H. Yu, E. S. Dawson, M. Li, O. McManus, C. K. Jones, J. S. Daniels, C. R. Hopkins, X. S. Xie, P. J. Conn, C. D. Weaver, C. W. Lindsley, ACS Chem. Neurosci. 2011, 2, $730 ;$ c) H. Miwa, J. Koh, Y. Kajimoto, T. Kondo, Pharmacol. Biochem. Behav. 2011, 97, 656.

[19] a) H. Miwa, T. Kondo, Cerebellum 2011, 10, 563 ; b) A. Handforth, G. E. Homanics, D. F. Covey, K. Krishnan, J. Y. Lee, K. Sakimura, F. C. Martin, A. Quesada, Neuropharmacology 2010, 59, 380.

[20] V. N. Uebele, A. L. Gotter, C. E. Nuss, R. L. Kraus, S. M. Doran, S. L. Garson, D. R. Reiss, Y. Li, J. C. Barrow, T. S. Reger, Z. Q. Yang, J. E. Ballard, C. Tang, J. M. Metzger, S. P. Wang, K. S. Koblan, J. J. Renger, J. Clin. Invest. 2009, 119, 1659.

[21] a) F. Sekiguchi, Y. Kawara, M. Tsubota, E. Kawakami, T. Ozaki, Y. Kawaishi, S. Tomita, D. Kanaoka, S. Yoshida, T. Ohkubo, A. Kawabata, Pain 2016, 157, 1655; b) J. H. Kim, G. Keum, H. Chung, G. Nam, Eur. J. Med. Chem. 2016, 123,665 ; c) F. Sekigushi, A. Kawabata, J. Pharmacol. Sci. 2013, 122, 244; d) A. François, N. Kerkhove, M. Meleine, A. Alloui, C. Barrere, A. Gelot, V. N. Ubele, J. J. Renger, A. Eschalier, D. Ardid, E. Bourinet, Pain 2013, 154, 283; e) W. J. Choe, R. B. Messinger, E. Leach, V.-S. Eckle, A. Obradovic, R. Salajegheh, V. JevtovicTodorovic, S. L. Todorovic, Mol. Pharmacol. 2011, $80,900$.

[22] a) V. S. Eckle, A. Shcheglovitov, I. Vitko, D. Dey, C. C. Yap, B. Winckler,E. Perez-Reyes, J. Physiol. 2014, 592, 795; b) G. W. Zamponi, P. Lory, E. Perez-Reyes, Pflugers Arch. 2010, 460, 395; c) K. L. Powell, S. M. Cain, C. Ng,
S. Sirdesai, L. S. David, M. Kyi, E. Garcia, J. R. Tyson, C. A. Reid, M. Bahlo, S. J. Foote, T. P. Snutch, T. J. O'Brien, J. Neurosci. 2009, 29 , 371; d) T. Broicher, T. Kanyshkova, P. Meuth, H. C. Pape, T. Budde, Mol. Cell Neurosci. 2008, 39, 384; e) S. E. Heron, H. Khosravani, D. Varela, C. Bladen, T. C. Williams, M. R. Newman, I. E. Scheffer, S. F. Berkovic, J. C. Mulley, G. W. Zamponi, Ann. Neurol. 2007, 62 , 560; f) H. Khosravani, G. W. Zamponi, Physiol. Rev. 2006, 86, 941; g) E. M. Talley, G. Solorzano, A. Depaulis, E. Perez-Reyes, D. A. Bayliss, Brain Res. Mol. Brain Res. 2000, 75, 159.

[23] C. Boss, J. Hazemann, T. Kimmerlin, M. von Korff, U. Lüthi, O. Peter, T. Sander, R. Siegrist, Chimia 2017, 71, 667.

[24] A. M. Coenen, E. L. van Luijtelaar, Behav. Genet. 2003, 33, 635 .

[25] O. Bezençon, L. Remen, S. Richard, C. Roch, M. Kessler, R. Moon, T. Pfeifer, E. A. Ertel, B. Capeleto, manuscript submitted.

[26] O. Bezençon, L. Remen, S. Richard, C. Roch, M. Kessler, R. Moon, T. Pfeifer, B. Capeleto, manuscript submitted,

[27] O. Bezençon, B. Heidmann, R. Siegrist, S Stamm, S. Richard, D. Pozzi, O. Corminboeuf, C. Roch, M. Kessler, E. A. Ertel, I. Reymond, T. Pfeifer, R. de Kanter, M. Toeroek-Schafroth, L. Moccia, R. Moon, M. Rey, B. Capeleto, E. Fournier, manuscript submitted.

[28] A. L. Hopkins, G. M. Keseru, P. D. Leeson, D. C. Rees, C. H. Reynolds, Nat. Rev. Drug Discov. 2014, 13, 105.

[29] a) B. N. Ames, Science 1979, 204, 587; b) K. Mortelmans, E. Zeiger, Mutat. Res. 2000, 455, 29.

[30] a) K.-T, Chung, L. Kirkovsky, A. Kirkovsky, W. A. Purcell, Mutat. Res. 1997, 387, 1; b) R. Benigni, L. Passerini, Matat. Res. 2002, 511, 191; c) R. Benigni, C. Bossa, T. Netzeva, A. Rodomonte, I. Tsakovska, Environ. Mol. Mutagen. 2007, 48, 754

[31] D. Barnes-Seeman, M. Jain, L. Bell, S. Ferreira S. Cohen, X.-H. Chen, J. Amin, B. Snodgrass, P. Hatsis, ACS Med. Chem. Lett. 2013, 4, 514.

[32] G. De Sarro, E. Russo, R. Citraro, B. S. Meldrum, Epilepsy Behav. 2017, 71 (Pt B), 165. 